\title{
Treasury's Unfinished Work On Corporate Expatriations
}

\section{Citation}

Stephen E. Shay, J. Clifton Fleming, Jr. \& Robert J. Peroni, Treasury's Unfinished Work On Corporate Expatriations, 150 Tax Notes (Feb. 22, 2016).

\section{Permanent link}

http://nrs.harvard.edu/urn-3:HUL.InstRepos:25499324

\section{Terms of Use}

This article was downloaded from Harvard University's DASH repository, and is made available under the terms and conditions applicable to Other Posted Material, as set forth at http:// nrs.harvard.edu/urn-3:HUL.InstRepos:dash.current.terms-of-use\#LAA

\section{Share Your Story}

The Harvard community has made this article openly available.

Please share how this access benefits you. Submit a story.

\section{Accessibility}




\section{POLICY PERSPECTIVE}

\section{Treasury's Unfinished Work On Corporate Expatriations}

\author{
By Stephen E. Shay, \\ J. Clifton Fleming Jr., and \\ Robert J. Peroni
}

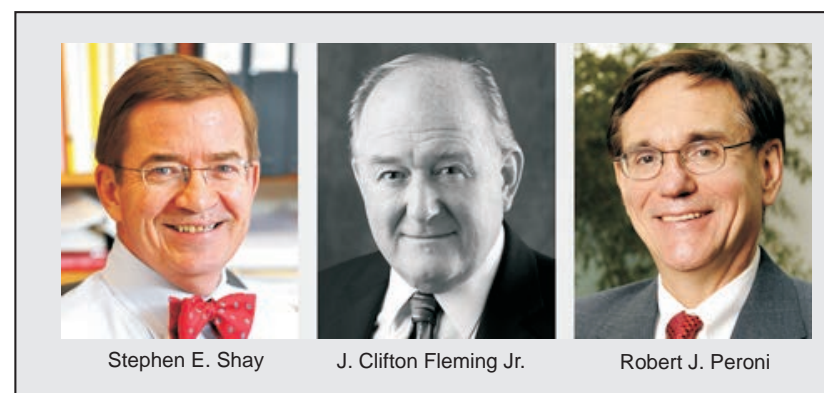

Stephen E. Shay is a senior lecturer at Harvard Law School. J. Clifton Fleming Jr. is the Ernest L. Wilkinson Chair and professor of law at Brigham Young University Law School. Robert J. Peroni is the Fondren Foundation Centennial Chair for Faculty Excellence and professor of law at the University of Texas School of Law. The authors thank Steven M. Rosenthal and readers who have asked to remain unidentified for helpful comments on earlier drafts of this article. Peroni thanks the University of Texas School of Law for its substantial summer research support and dedicates this article to his loving parents, Betty Peroni and the late Emil Peroni, for their tremendous support and inspiration over the years. The views expressed by the authors in this article are their own and do not reflect those of their universities, any organization with which they are affiliated or, in the case of Shay, any client.

Continued tax-motivated inversions highlight the systemic tax advantages that a foreign-owned U.S. corporation has over a U.S.-owned corporation in avoiding U.S. corporate tax on U.S. business income. This article emphasizes the need for Treasury to further reduce U.S. tax incentives for inversions and other foreign acquisitions of U.S. corporations. It identifies ways in which Treasury can address the two most important tax incentives: earnings stripping and the ability to use a U.S. group's unrepatriated foreign earnings to benefit foreign parent shareholders without incurring current U.S. income tax.

Copyright 2016 Stephen E. Shay, J. Clifton Fleming Jr., and Robert J. Peroni. All rights reserved.

\section{A. Introduction}

Corporate expatriations are back in the news. Leading the way is a potential blockbuster transaction in which the massive U.S. drug company Pfizer Inc. would be acquired by the smaller Allergan PLC, an Irish receptacle for serial inversions of former U.S. companies Actavis, Forest Laboratories, and Allergan. ${ }^{1}$ The Pfizer-Allergan transaction is designed to avoid the reach of the statutory rule that restricts some of the tax benefits of an inversion. ${ }^{2}$ Other transactions within the reach of the statutory anti-inversion rule - but not discomfited by it because the acquiring foreign corporation is not reclassified as a U.S. corporation for tax purposes - are attracting less attention but also highlight the continued advantages of having a U.S. business owned by a foreign parent company. ${ }^{3}$

The motivation for this article is twofold: (1) to reemphasize the need to reduce the U.S. tax incentives for inversion-type acquisitions, ${ }^{4}$ and (2) to

\footnotetext{
${ }^{1}$ Kevin McCoy, "Experts: U.S. Unlikely to Block PfizerAllergan Deal," USA Today, Nov. 23, 2015.

${ }^{2}$ Section 7874(a) and (b) specifies that a "surrogate foreign corporation" has some U.S. income tax disadvantages. Section 7874(a)(2)(B) provides in part that a foreign acquiring corporation will be a "surrogate foreign corporation" if, inter alia " after the acquisition at least 60 percent of the stock (by vote or value) of the entity is held ... by former shareholders of the domestic corporation by reason of holding stock in the domestic corporation." This condition reportedly would not be satisfied in the Pfizer-Allergan transaction. The recently announced Johnson Controls-Tyco transaction will use a similar approach.

${ }^{3}$ See Donald J. Marples and Jane G. Gravelle, "Corporate Expatriation, Inversions, and Mergers: Tax Issues," Congressional Research Service report R43568 (Nov. 30, 2015), at 11-12. Lower-profile transactions have been structured to work within the statutory and regulatory rules affecting the benefits from inversions. Marples and Gravelle identify post-Notice 2014-52 transactions between, respectively, ARRIS International PLC (U.S.) and Pace PLC (U.K.), CF Industries (U.S.) and OCI NV Corp. (Netherlands), Terex PLC (U.S.) and Konecranes (Finland), and Coca-Cola Enterprises Inc. (U.S.) and European Coke bottlers. See also Cathy Hwang, "The New Corporate Migration: Tax Diversion Through Inversion," 80 Brooklyn L. Rev. 807, 820-837 (2015) (reviewing inversion transactions and government responses).

${ }^{4}$ See Stephen E. Shay, "Mr. Secretary, Take the Tax Juice Out of Corporate Expatriations," Tax Notes, July 28, 2014, p. 473 (urging Treasury to take regulatory steps to reduce tax incentives for inversions by strengthening earnings-stripping limitations and investment in U.S. property rules under section 956).
} 
emphasize that Treasury has available unused administrative actions that would further reduce material tax incentives for inversions and other foreign acquisitions of U.S. corporations. 5 To date, Treasury has taken calibrated steps in the context of inversions (as narrowly defined in section 7874) to reduce the tax advantages of smaller foreign corporations acquiring larger U.S. corporations. Congress, unfortunately, has taken no action at all. ${ }^{6}$ The renewed market pressure for tax-motivated inversions and, increasingly, other foreign acquisitions of U.S. corporations, threatens Treasury's institutional credibility if it fails to take actions that are commensurate with the risk to the U.S. tax base. $^{7}$

\footnotetext{
"The term "inversion" is sometimes used to refer only to transactions described in section 7874 and more colloquially to refer to any transaction or series of transactions in which a smaller foreign corporation in form acquires a larger U.S. corporation but thereafter is more than 50 percent owned and controlled by shareholders of the former U.S. parent corporation. Indeed, legislative proposals have been introduced to amend - and the administration has a budget proposal that would amend - section 7874 to reduce the threshold to 50 percent to trigger classification of the foreign acquiring corporation as a U.S. corporation or alternatively to trigger inclusion of previously untaxed earnings. See, e.g., "Stop Corporate Inversions Act of 2014," H.R. 4679, 113th Cong., 2d Sess. (May 20, 2014) (sponsored by Reps. Levin, Rangel, McDermott, Neal, Doggett, Larson, Danny K. Davis, Van Hollen, Delauro, and Schakowsky); "Pay What You Owe Before You Go Act," S. 2895 , 113th Cong., 2d Sess. (Sept. 18, 2014) (sponsored by Sens. Brown and Durbin); Treasury, "General Explanations of the Administration's Fiscal Year 2016 Revenue Proposals" (Feb. 2015), at 37-38.
}

${ }^{6}$ Instead, in December 2015, Congress passed and the president signed into law massive tax extender legislation that is estimated to lose a net $\$ 622$ billion in revenue over 10 years. The legislation was a carefully balanced Christmas tree of gifts that extended, and in some cases expanded, tax benefits for both low- and middle-income individuals as well as for both small businesses and large multinational businesses. The tax extenders legislation is evidence of continued congressional inability to increase the net tax burden on any material group of taxpayers, and it foreshadows dim prospects for meaningful tax reform.

${ }^{7}$ See, e.g., Steven Davidoff Solomon, "Corporate Inversions Aren't the Half of It," The New York Times, Feb. 10, 2016, at B5 ("If you thought there was a problem with inversions - deals that allow American companies to relocate their headquarters to lower their tax bills - wait until you hear about the real secret to avoiding corporate taxes. It's called earnings stripping, and it is a technique that the Obama administration has so far failed to stop. ... But for now, rules limiting this type of behavior seem to be a pipe dream. Instead, the corporate runaways are winning - winning no good-American awards, but taking easy money out of the pockets of the United States taxpayer."). In other work, we have explained why the United States will likely have to continue to rely on the corporate income tax as a revenue source for the foreseeable future. See Shay, J. Clifton Fleming Jr., and Robert J. Peroni, “Designing a 21st Century Corporate Tax - An Advance U.S. Minimum Tax on Foreign Income and Other Measures to Protect the Base," 17 Fla. Tax Rev. 669, 676-678 (2015).
U.S. corporate expatriation transactions are a symptom of a structural problem in the U.S. corporate tax: Specifically, foreign-owned multinational corporations (MNCs) have systemic tax advantages over U.S. MNCs in their ability to avoid U.S. corporate tax on U.S. income. The tax advantages of owning a U.S. business with a foreign instead of a U.S. parent corporation are not limited to cases in which U.S. corporations are acquired by smaller foreign corporations in an inversion, and these advantages cannot be eliminated by reducing the U.S. corporate income tax rate to 25 percent. Indeed, these advantages will be exacerbated by replacing the U.S. international income tax system with a territorial system.

This article argues that until legislative reforms can achieve a better balance in the taxation of U.S. and non-U.S. MNCs, and regarding U.S. business income in particular, Treasury should take immediate administrative actions - in the form of enforcing existing regulations and adopting new or expanded regulations - to reduce the systemic tax advantages afforded to foreign ownership of U.S. corporations that are drivers of tax-motivated inversions and other foreign acquisitions of U.S. corporations. In light of the continued absence of prospects for legislative reforms, this article identifies administrative actions available to Treasury and the IRS that would restrict the principal tax drivers of corporate expatriations: earnings stripping and avoidance of tax on offshore earnings. ${ }^{8}$

In making the case for these actions, this article continues a theme in our recent work and testimony before Congress. Source and residence taxation are integrally linked in any system's taxation of crossborder income. ${ }^{9}$ Taxation of residents' foreign income is important to protect against the use of

\footnotetext{
${ }^{8}$ There is little genuine consensus regarding the details of tax reform generally and international tax reform in particular. The oft-touted supposed convergence on the direction of international tax reform masks deep-seated differences on whether and how much the United States should tax foreign income. The administration's fiscal 2016 budget proposals for international tax changes were designed to meet moderate Republican proposals partway, but they have drawn sharp objections from Sen. Elizabeth Warren, D-Mass., and even presidential candidate Hillary Clinton's campaign proposals take a more aggressive approach. See Treasury, "General Explanations of the Administration's Fiscal Year 2017 Revenue Proposals," 2-288 (Feb. 2016); Warren, "Remarks at the National Press Club" (Nov. 18, 2015); see, e.g., Clinton, "Ending Inversions and Investing in America" (Dec. 8, 2015). Moreover, the tax reform proposals to date do not fully address the structural tax advantages of foreign over domestic parent corporate groups in avoiding U.S. corporate tax on domestic income. Stated differently, international tax reform is not yet ready for prime time.

${ }^{9}$ See Fleming, Peroni, and Shay, "Getting Serious About Cross-Border Earnings Stripping: Establishing an Analytical
} (Footnote continued on next page.) 
offshore structures to avoid taxation of residents' domestic income. In turn, correcting the deficiencies in source taxation of nonresidents' domestic income is critical to more closely approach neutrality with purely domestic and U.S. multinational businesses and to reduce the incentive for U.S. multinationals to invert or otherwise become foreign-owned. ${ }^{10}$

\section{B. Systemic Foreign Parent Tax Advantages}

U.S. corporations that engage in corporate expatriation transactions seek four potential tax advantages unavailable to a U.S.-parent multinational:

1. the ability to use intercompany borrowing (or intangibles licenses) from a foreign affiliate to generate earnings-stripping payments from the U.S. corporate tax base;

2. the use, directly or indirectly, of a U.S. group's unrepatriated foreign earnings for the benefit of U.S. shareholders of the foreign parent corporation;

3. the ability to sell U.S.-located inventory into the U.S. market without U.S. tax; and

4. avoidance of U.S. residual tax on foreign earnings of foreign affiliates that are not owned by a U.S. company.

This article addresses the first two advantages, which are the most significant market drivers of corporate expatriations. ${ }^{11}$

The third advantage, to be able to sell into the U.S. market from U.S.-located inventory without U.S. tax, is an important structural issue and should receive attention in international tax reform proposals. ${ }^{12}$ There is need for a fundamental reexamina-

Framework," 93 N.C. L. Rev. 672, 682 (2015); Shay, Fleming, and Peroni, supra note 7, at 692-699, 719-722; "Testimony of Stephen E. Shay Before the U.S. Senate Committee on Finance, Hearing on Building a Competitive U.S. International Tax System" (Mar. $17,2015)$, at 8-9.

${ }^{10}$ See Shay, Fleming, and Peroni, supra note 7 , at 717-721 (outlining reforms to strengthen source taxation to better balance residence and source taxation). Proposals in the G-20 and OECD project on base erosion and profit shifting (and the U.K diverted profits tax and draft EU anti-tax avoidance directive) also target protection of the source tax base as other countries combat the effects that international adoption of partial exemption regimes places on the source tax base. Corporate expatriations by U.S. multinationals highlight the importance of BEPStype reforms for the United States.

${ }^{11}$ See Shay, supra note 4, at 479; Hwang, supra note 3, at 812-817; Treasury, "Report to the Congress on Earnings Stripping, Transfer Pricing and U.S. Income Tax Treaties" (Nov. 2007), at 21-22. See also Jim A. Seida and William Wempe, "Effective Tax Rate Changes and Earnings Stripping Through Corporate Inversion," 57 Nat. Tax J. 805 (2004).

${ }^{12}$ See, e.g., sections 864(c)(3)-(5), 865(b), 865(e)(2), and 894(a) (a treaty eligible foreign corporation that does not have a U.S. permanent establishment (directly or by attribution under rules comparable to reg. section 1.864-7) can avoid U.S. tax on

(Footnote continued in next column.) tion of how to structure source country taxation that is neutral in effect, not just form, in taxation of a domestic taxpayer seller and a remote foreign seller into the domestic market. ${ }^{13}$ The ability of many businesses to exploit a market without being present in the market for tax purposes (at least under current law), requires a rethinking of the antiquated paradigm that some form of physical direct presence is required for a source country to tax material economic returns from a market. ${ }^{14}$ This important subject is beyond the scope of this article. ${ }^{15}$

The fourth advantage, avoiding U.S. residual tax on foreign earnings of a foreign affiliate, offers no financial statement benefit compared with accumulated foreign earnings of a controlled foreign corporation if the earnings of the CFC are not distributed

business profits from sales from U.S.-located inventory). While there is broad scope for a U.S.-owned corporation to engage in that type of strategy regarding export sales (although there is execution risk), the investment in U.S. property rules effectively mitigate its advantages regarding U.S.-destination sales. See section 956(c)(2)(B); cf. Jeffrey M. Kadet, "Attacking Profit Shifting: The Approach Everyone Forgets," Tax Notes, July 13, 2015, p. 193 (arguing that the IRS should attack offshore profit shifting by pursuing claims that a CFC's income is taxable as effectively connected income).

${ }^{13}$ U.S. international tax policy debates regarding "homeless" or "stateless" income have long been dominated by a focus on avoidance of residence-based taxation and far less on avoidance of U.S.-source taxation. See Edward D. Kleinbard, "Stateless Income's Challenge to Tax Policy," Tax Notes, Sept. 5, 2011, p. 1021; Kleinbard, "Stateless Income's Challenge to Tax Policy, Part 2," Tax Notes, Sept. 17, 2012, p. 1431; Kleinbard, "The Lessons of Stateless Income," 65 Tax L. Rev. 99 (2011). Bret Wells and Cym Lowell, however, have focused attention on weaknesses in source taxation and proposed enhanced source taxation measures. See Wells and Lowell, "Tax Base Erosion: Reformation of Section 482's Arm's-Length Standard," 15 Fla. Tax Rev. 737, 784-786 (2014); Wells and Lowell, "Tax Base Erosion and Homeless Income: Collection at Source Is the Linchpin," 65 Tax L. Rev. 535 (2011). One commentator recently has focused on attacking U.S. base erosion by CFCs through stronger enforcement of the U.S. effectively connected income rules. See, e.g., Kadet, supra note 12 (arguing that the IRS should attack offshore profit shifting by pursuing claims that a CFC's income is taxable as effectively connected income).

${ }^{14}$ The ability of Microsoft Corp. to exploit the U.S. market from Puerto Rico is a paradigmatic example. See Senate Homeland Security and Governmental Affairs Permanent Subcommittee on Investigations, "Hearing on Offshore Profit Shifting and The U.S. Tax Code, Exhibit 1, Memorandum from Chairman Carl Levin and Sen. Tom Coburn to Subcommittee Members, Offshore Profit Shifting and the Internal Revenue Code" (Sept. 20,2012 ), at 20-22. Similarly, the ability of Swiss-based Nestle SA to perform research in the United States and later make sales using intellectual property developed from that research but owned in Switzerland is a comparable foreign parent example of the same phenomenon. See Wells and Lowell, "Collection at Source," supra note 13.

${ }^{15}$ See generally Fleming, "A Note on the Zimmer Case and the Concept of Permanent Establishment," in Michael Lang et al., eds., Tax Treaty Case Law around the Globe - 2011, at 107 (2011) available at http:/ / ssrn.com/abstract=2079317. 
and are "indefinitely reinvested" outside the United States. Accordingly, the impact of this fourth "benefit" depends significantly on the location of cash flow generation and whether there is a need to distribute foreign earnings to a U.S. group member. In most cases, the fourth advantage is not a market driver for corporate expatriation because it does not produce a material reduction in the corporation's financial statement effective tax rate. ${ }^{16}$

\section{Admin Actions to Reduce U.S. Base Erosion}

1. U.S. base erosion: Earnings stripping. One of us has previously advocated for regulatory action regarding earnings stripping. ${ }^{17}$ Treasury's initial response to inversions in Notice 2014-5218 did not address earnings stripping. While some taxmotivated inversion transactions affected by the notice's rules did not occur, other transactions that appeared to benefit substantially from earnings stripping (such as the Medtronic-Covidien transaction) did proceed. Thus, it was disappointing that Treasury's later-issued Notice 2015-7919 did not take up earnings stripping.

In December 2015, following the issuance of Notice 2015-79, W. Anthony Will, the CEO of CF Industries Holdings Inc. (CF), a company involved in a proposed inversion transaction, said that his company will engage in earnings stripping as long as it is allowed. Will said that if the earnings-stripping benefit were unavailable, $\mathrm{CF}^{\prime}$ 's projected tax rate after its inversion with Dutch-based OCI NV would increase from an estimated 20 percent to "the midtwenties." 20 Based on pro forma combined pretax 2014 earnings of $\$ 1.6$ billion and assuming a 5 percent increase in tax rate, it may be estimated that CF anticipates reaping more than $\$ 80$ million annually in tax benefits from earnings stripping. Over a 10year budget period without any inflation, the earnings-stripping revenue loss from that one transaction could be $\$ 800$ million. Treasury should relieve CF's CEO of the burden of having to erode the U.S. tax base solely because of this legal planning opportunity in a transaction he claims will be carried out in any event.

An important tax policy objective is to assure that U.S. businesses are taxed equivalently whether they are U.S.- or foreign-owned. If a foreign-owned CF

\footnotetext{
${ }^{16}$ Willard B. Taylor, "A Comment on Eric Solomon's Article on Corporate Inversions," Tax Notes, Oct. 1, 2012, p. 105.

${ }^{17}$ Shay, supra note 4, at 474-476; Fleming, Peroni, and Shay, "Getting Serious," supra note 9.

${ }^{18} 2014-42$ IRB 712.

${ }^{19} 2015-49$ IRB 775.

${ }^{20}$ Will emphasized that the CF-OCI deal was not premised on earnings stripping and would proceed if the earnings-stripping benefit were diminished or even eliminated.
}

can save $\$ 800$ million or more in taxes compared with a U.S.-owned CF carrying on the same activity, there is a systemic failure to achieve neutral corporate taxation of U.S.- and foreign-owned U.S. corporations. Generally, a U.S. parent group cannot achieve the same earnings-stripping benefit using a foreign subsidiary because the foreign subsidiary would be a $\mathrm{CFC}^{21}$ and its interest income from a loan to a U.S. affiliate would be subpart F income includible currently in the income of its U.S. parent.22

Treasury has regulatory authority to remedy this defect by adopting earnings-stripping restrictions through regulatory action. ${ }^{23}$ After Shay's 2014 article, Shay and Steven M. Rosenthal of the UrbanBrookings Tax Policy Center outlined for Treasury alternative regulatory approaches for implementing earnings-stripping restrictions using section 385 that were released under the Freedom of Information Act. ${ }^{24}$ The earnings-stripping proposal using section 385 authority outlined there - after Treasury in Notice 2014-52 preserved an immediate effective date for future earnings-stripping action in relation to inversions - would not be restricted to expatriating entities (except for application of the earlier effective date).

Treasury's two responses to inversions in Notice 2014-52 and Notice 2015-79 have not addressed earnings stripping. Moreover, they generally have limited the scope of their antiavoidance changes to expatriating entities (except for a regulation under section 304 to prevent transfers of earnings and profits out of U.S. tax reach). The base erosion problem today is broader and deeper than in 2014, and the failure to act is inducing more taxpayers to

\footnotetext{
${ }^{21} \mathrm{~A} C \mathrm{CFC}$ is a foreign corporation that is more than 50 percent owned, by vote or value, directly, indirectly, or by attribution, by any U.S. shareholders. Section 957(a). A U.S. shareholder is a U.S. person that owns, directly, indirectly, or by attribution, 10 percent or more of the voting power of the stock of the foreign corporation. Section 951(b).

${ }^{22}$ See Fleming, Peroni, and Shay, "Getting Serious," supra note 9 , at 682

${ }^{23}$ One of us has previously written that the IRS and Treasury may take strong actions against U.S. earnings stripping by foreign parent groups using existing regulatory authority. See Shay, supra note 4, at 474-476. For a contrary view on Treasury's legal authority, see Stuart L. Rosow and Martin T. Hamilton, "A Response to Professor Shay: Leave Inversions to Congress," Tax Notes, Sept. 8, 2014, p. 1187. For a supporting view, see Steven M. Rosenthal, "Professor Shay Got It Right: Treasury Can Slow Inversions," Tax Notes, Sept. 22, 2014, p. 1445; Samuel C. Thompson Jr., "Professor Says Debt/Equity Regs Can Apply to Inversions," Tax Notes, Aug. 18, 2014, p. 883. We are unaware of a reasoned analysis that rebuts Rosenthal's and Thompson's analysis of the authority under section 385 to adopt targeted debt-equity regulations.

${ }^{24}$ See Shay and Rosenthal, "Individuals Submit Earnings Stripping Proposals to Treasury" (Oct. 2, 2014).
} 
seek earnings-stripping benefits of foreign ownership - even a company such as CF that, according to its 2014 Form 10-K segment disclosure, holds 90 percent of its assets and makes 80 percent of its sales in the United States. Strong and decisive action against earnings stripping (that is not limited to expatriating entities) is overdue.

Regulations under the authority of section 385 could be designed to limit U.S. tax base erosion in various ways. One approach that we could support would be to recast as an equity interest any corporate debt obligation that meets the following criteria: the corporate debtor would otherwise be eligible for interest deductions regarding the obligation and the obligation is held (or guaranteed) by a related person not subject to U.S. tax on the income from the obligation (related-person debt). The standards of the earnings-stripping rules would be used for this purpose. ${ }^{25}$ We would be comfortable with an exception for financial services entities and a de minimis exception for a taxpayer that has less than $\$ 5$ million of net interest expense, similar to those in the administration budget proposal restricting excessive interest.

Regulations would set forth two factors that would determine when holding related-person debt is indicative of a shareholder-corporation relationship and not a creditor-debtor relationship. Under these regulations, related-person debt would be classified as equity if either of the following factors is met:

- First, upon issuance of the obligation, the issuing corporation (or its U.S. affiliated group) had a debt-to-equity ratio that exceeds the lesser of (1) 1.25 to 1, or (2) 110 percent of the average debt-equity ratio of the affiliated group. ${ }^{26}$ An amount of principal of the obligation that causes the debt-equity ratio to exceed the applicable ratio (stacking unrelated-party

\footnotetext{
${ }^{25}$ The definitions of "related person" and "subject to tax" would be the same as those in section 163(j)(3)(A).

${ }^{26}$ For this purpose, debt is defined as the total indebtedness of the corporation (excluding short-term liabilities), and equity is the sum of money and the adjusted basis of all other assets reduced by the total indebtedness. See prop. reg. section 1.163(j)-3. Also, the rule would treat consolidated return participants as a single taxpayer, net interest expense would be as defined in section 163(j)(6)(B), and adjusted taxable income would be as defined in section 163(j)(6)(A). The text describes a bifurcation approach to reclassifying an instrument, which allows greater fine tuning of the amount of disallowed interest. Bifurcation, however, would be more complex than classifying an instrument as debt or equity in its entirety. If an all or nothing classification approach were preferable, because the proposal only applies to related parties, it would be possible for the parties to redeem excessive debt and reissue a lesser principal amount. Accordingly, we could support either approach.
}

debt first) would be classified for all U.S. federal income tax purposes as equity.

- Second, if the net interest expense of an obligor on related-person debt exceeds 25 percent of its adjusted taxable income (each averaged over the current and prior two years), all newly issued related-person debt would be subject to reclassification as equity without regard to the preceding paragraph. To the extent that interest paid or accrued on newly issued relatedperson debt caused the ratio of related-person debt interest to adjusted taxable income to exceed 25 percent of its three-year average, the related-person debt would be classified as equity based on the ratio of the excess to the total amount of interest on the related-person debt for the year.

The testing date for the related-person debt would be the last day of the tax year in which the obligation was issued. For this purpose, an obligation is treated as reissued if the obligation is (1) subordinated to later debt (other than short-term liabilities), or (2) later guaranteed. These standards are in addition to the rules under section 1001 for debt reissuance. The regulations should be effective for obligations issued on or after the date guidance is issued or in connection with an inversion transaction (defined under section 7874 as it is in effect on the date of issuance) that is completed on or after September 22, 2014. ${ }^{27}$

The details and thresholds of the regulations should be based on tax return data available to the IRS and Treasury. The thresholds identified in the proposal above are drawn from prior proposals and, indeed, may be too generous. We leave those decisions appropriately to the discretion of the regulation writers. (It should be recognized that regulations are only watered down, not strengthened, in the notice and comment process.) What is important is to act - or Treasury risks losing further credibility with taxpayers and in the taxavoidance marketplace.

2. U.S. base erosion: Avoiding residual U.S. tax on unrepatriated CFC earnings. The Pfizer-Allergan transaction brings the focus to unrepatriated foreign earnings of U.S. MNCs. ${ }^{28}$ As of the end of 2014, Pfizer had a reported $\$ 74$ billion of book earnings indefinitely reinvested outside of the United States

\footnotetext{
${ }^{27}$ The earlier effective date is to honor the effective date announced in Notice 2014-52.

${ }^{28}$ Pfizer would not appear to reap short-term tax (and financial statement) benefits from earnings stripping. Pfizer's fiscal $201410-\mathrm{K}$ financial statement tax footnote reports a $\$ 4.7$ billion U.S. operating loss, so the presumption is that use of intercompany debt for earnings stripping does not offer a short-term benefit, though it may be very helpful in the future.
} 
and approximately $\$ 21$ billion of book-deferred taxes on additional unrepatriated earnings that were not "indefinitely reinvested" outside the United States. ${ }^{29}$ Pfizer has emphasized the benefit of "increased financial flexibility" resulting from the transaction with Allergan. One interpretation of this somewhat opaque language is that Pfizer may hope to use its untaxed CFC earnings for the benefit of shareholders of the foreign parent company without triggering U.S. tax. Whether this is Pfizer's expectation, use of such earnings for shareholder purposes would be inconsistent with the policy underlying section 956 .

This part of the article observes that (1) use of CFC earnings for the benefit of a new foreign parent should be subject to an existing antiabuse regulation; and (2) if the reach of the antiabuse regulation is avoided by "decontrolling" the foreign affiliate, Treasury can and should expand the coverage of the decontrol rules of Notice 2014-52 beyond section 7874 inversions to cases in which any foreign acquirer would achieve an advantage in relation to pre-effective-date earnings. To set the stage for the following discussion, it may be helpful to review the relevant tax rules.

a. Background on deemed dividends from investments in U.S. property. Active business income earned by a CFC generally is not taxed by the United States until the earnings are repatriated as an actual or deemed dividend. ${ }^{30}$ This delay in taxation until a CFC's earnings are remitted is known as deferral. Deferral comes with a price, however. A U.S. multinational's use of the untaxed CFC earnings, directly or indirectly, in its U.S. business or to finance its U.S. business can -in a wide range of circumstances under section 956 trigger a deemed dividend of those earnings and end deferral. ${ }^{31}$ In this part of the article, we explore the potential reach of those rules, including as they were amended in a September 2015 temporary regulation. ${ }^{32}$

\footnotetext{
${ }^{29}$ Pfizer 2014 Form 10-K, at 81. If Pfizer could persuade its auditors that it did not have to pay residual U.S. tax on the earnings for which it already has booked the tax, reversing those tax reserves would bolster its reported net earnings.

${ }^{30}$ Sections 301 and 956.

${ }^{31}$ This article uses the terms "untaxed" and "untaxed earnings" colloquially to refer to after-foreign-tax foreign subsidiary earnings that have not been subjected to U.S. taxation.

${ }^{32}$ T.D. 9733, 80 F.R. 52976-52982 (Sept. 2, 2015), amending reg. section 1.956-1T(b)(4); corrected 80 F.R. 66415-66416 (Oct. 28, 2015).
}

Under section 956, the amount of a CFC's untaxed foreign earnings that is considered to be invested in some U.S. property is treated as though it was distributed to the CFC's U.S. parent company and included in income. ${ }^{33}$ These rules classify a CFC's loan to its U.S. parent or a U.S. affiliate as an investment in U.S. property. ${ }^{34}$ Because it would be relatively easy to avoid the reach of this lending rule through indirect credit support, section 956(d) and (e) backstop the preceding rules with broad grants of regulatory authority. ${ }^{35}$ Treasury has used this regulatory authority to treat an indirect use of a CFC's assets in support of a loan to the CFC's U.S. parent as an investment in U.S. property. ${ }^{36}$

\footnotetext{
${ }^{33}$ In this article, references to "U.S. parent" or "U.S. affiliate" assume that they are a U.S. shareholder, as defined in section 951(b) in relation to the foreign subsidiary. Using the technical terms, section 951(a)(1)(B) requires a U.S. shareholder of a CFC to include in income its allocable portion of investments made or deemed made "directly or indirectly" by the CFC in U.S. property (section 956 inclusions). The amount of the investment in U.S. property is the average quarterly balance of the CFC's adjusted tax basis in U.S. property, reduced by any liability to which the property is subject, to the extent of untaxed earnings. Using a concept of "applicable earnings," this amount is reduced by previous section 956 inclusions that have not actually been distributed. See sections 951, 956, and 959.

${ }^{34}$ Section 956(c)(1)(C).

${ }^{35}$ Subsections (d) and (e) state:

(d) Pledges and guarantees.

For purposes of subsection (a), a controlled foreign corporation shall, under regulations prescribed by the Secretary, be considered as holding an obligation of a United States person if such controlled foreign corporation is a pledgor or guarantor of such obligation.

(e) Regulations.

The Secretary shall prescribe such regulations as may be necessary to carry out the purposes of this section, including regulations to prevent the avoidance of the provisions of this section through reorganizations or otherwise.

In addition to section 956(d) and (e), regulatory authority in this area may derive from section 7701(1) as well as section 7805 . See Shay, supra note 4 , at 476 .

${ }^{36}$ If a loan to a U.S. parent or U.S. affiliate is secured by a pledge or guarantee by the foreign subsidiary, or if the foreign subsidiary's assets serve as indirect security for the loan (including through a pledge of at least $66^{2} / 3$ of the stock entitled to vote accompanied by negative covenants on the use of assets), the foreign subsidiary is deemed to make an investment in U.S. property. Reg. section 1.956-2(c). See Ken Brewer, "Open Questions Regarding Pledges and Guarantees by CFCs," Tax Notes, Jan. 21, 2002, p. 359.
} 
In Notice 2014-52, the IRS used its regulatory authority to treat a loan to a foreign related person by an expatriated foreign subsidiary (generally, a CFC that has an expatriated entity as a U.S. shareholder) as an investment in U.S. property. ${ }^{37}$ As the Pfizer and other transactions show, however, it is not enough to limit the scope of the rule to a CFC that is a subsidiary of an expatriated entity as defined for purposes of section 7874. A simple "fix" would be to revise the Notice 2014-52 rules to cover any case in which a $\mathrm{CFC}$ has an ultimate foreign parent. This scope for "indirect" ownership of U.S. property is supported by the regulatory authority cited above, including in cases that did not involve an acquisition of the U.S. group. If there were concerns about this authority in non-acquisition cases, which we do not think should be the case, the treatment of a loan of untaxed CFC earnings to a foreign related person as an investment in U.S. property could be made rebuttable if a principal purpose of the arrangement was other than to avoid section 956 .

b. The reach of the existing antiavoidance regulation. Importantly, an existing temporary regulation already reaches many of these cases. Reg. section 1.956-1T(b)(4)(i)(B), which dates from 1988, provides that under some circumstances, U.S. property owned by another foreign corporation may be considered indirectly held by a CFC subject to the deemed dividend rules of section 956. The scope of this regulation is very broad, and this part considers its potential application to simplified cases through illustrative examples.

Example 1: A publicly traded U.S. corporation (USP) wholly owns a CFC organized in Country A (CFC 1). CFC 1 has substantial accumulated earnings and profits. Publicly traded foreign corporation (FP) is organized in Country B. FP acquires USP for FP stock. Assume that for purposes of the U.S. anti-inversion rules, ${ }^{38}$ immediately after the transaction former shareholders of USP own less than 60 percent of FP. After the transaction FP wholly owns USP, which continues to wholly own CFC 1. CFC 1 makes a loan to FP, which uses the loan to finance buybacks of FP stock. (This kind of loan is sometimes called a "hopscotch" loan because it bypasses USP.) It is assumed that (1) FP has not made a loan to USP, (2) USP does not have an outstanding obligation to make a loan to FP, and (3) absent application of section 956, the hopscotch loan would not otherwise be found to be a constructive dividend to USP. The diagram below illustrates the transaction:

\footnotetext{
${ }^{37}$ Notice 2014-52, 2014-52 IRB 712, 717-718, section 3.01.

${ }^{38}$ See section 7874 .
}

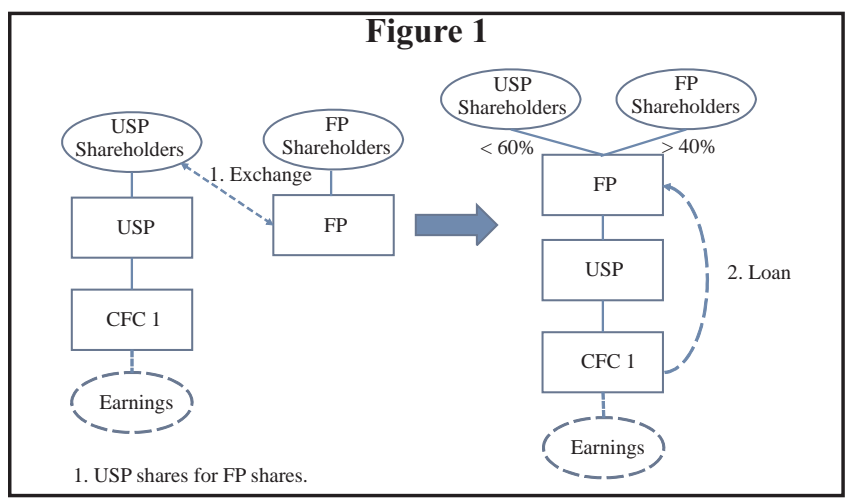

The question is whether section 956 would apply to cause the loan from CFC 1 to FP to be considered an investment in U.S. property. Reg. section 1.9561T(b)(4)(i)(B) states that under some circumstances, U.S. property owned by another foreign corporation may be considered indirectly held by a foreign subsidiary that is subject to the deemed dividend rules of section 956 . The required conditions framed in terms of Example 1 above are:

1. CFC 1 "controls" FP (by virtue of being related within the meaning of section 267(b));

2. FP acquires U.S. property; and

3. "A principal purpose of creating, organizing, or funding by any means (including through capital contributions or debt)" FP is to avoid the application of section 956 with respect to CFC 1.39

Before explaining how these conditions are satisfied, it is worthwhile to focus on what is not required by the temporary regulation. First, the "funding" of the foreign corporation is not required to precede ownership of the U.S. property. ${ }^{40}$ Second, the "funding" is not required to be from the CFC whose earnings are subject to inclusion. Indeed, the "funding" can come from an unrelated person. ${ }^{41}$

The three conditions above are each satisfied in Example 1. CFC 1 controls FP for this purpose because it and FP are related "within the meaning of section 267(b)." 42 Under section 267(b), CFC 1

\footnotetext{
${ }^{39}$ Reg. section 1.956-1T(b)(4)(i)(B). This article does not address whether other portions of the temporary regulation relating to creating or organizing the foreign corporation may also apply.

${ }^{40}$ Note that a similar approach is taken in the IRS's adoption in Notice 2014-32, 2014-20 IRB 1006, of an antiabuse rule in the anti-Killer B context. Notice 2014-32, 2014-20 IRB 1006, 1008, section 4.03 (last sentence)

${ }^{41} \mathrm{~A}$ similar approach is taken in the preamble's explanation in T.D. 9477 of reg. section 1.304-4T and its interpretation that "funding" includes unrelated person funding.

${ }^{42}$ Reg. section 1.956-1T(b)(4)(ii).
} 
and FP are related if they are in one of the relationships described in that subsection, which includes a parent-controlled subsidiary group. ${ }^{43}$

FP's stock in USP is U.S. property. ${ }^{44}$ The temporary regulation does not require that the U.S. property be linked with the "funding." 45

The third condition is that "a principal purpose of ... funding [FP] by any means (including through capital contributions or debt)" is to avoid the application of section $956 .{ }^{46}$ In this case, the funding by CFC 1 of FP via the CFC 1 loan should be considered to have a principal purpose of avoiding section 956. Having a majority of former USP shareholders would not seem to be a necessary condition if avoiding section 956 is "one of" the principal purposes of the funding of FP.

What are the limits of the principal purpose condition? Does the analysis change if CFC 1 generates material post-transaction earnings? CFC 1's earnings are irrelevant except for the section 956(a)(2) applicable earnings limitation. Regarding that limitation, it makes no difference whether earnings are pre- or post-acquisition.

Does the analysis change if the loan proceeds are not used by FP for stock buybacks but are used in its non-U.S. business? This depends on the rationale for finding a principal purpose of avoidance in the first case. Is it because the loan is indirectly for the benefit of former shareholders of USP or because the earnings are used to hold an obligation of a related person that is outside the scope of U.S. taxing jurisdiction (as opposed to a loan to a CFC)? ${ }^{47}$

In Notice 2014-52, any stock or obligation of a "non-CFC foreign related person" after a section 7874 inversion is treated as an indirect investment in U.S. property. ${ }^{48}$ The rationale of this rule is that there is a principal purpose to avoid section 956 when untaxed CFC earnings are made available to a related person to earn returns that are not subject

\footnotetext{
${ }^{43}$ See sections 267(b), (f), and 1563(a)(1); reg. section 1.9561T(b)(4)(i); reg. section 1.1563-1(a)(2)(ii), Example 1.

${ }^{44}$ Section 956(c)(1)(B). On the facts of Example 1, the requirements for the exception in section 956(c)(2)(F) are not met.

${ }^{45}$ See reg. section 1.956-1T(b)(4)(iv), Example 2. Reg. section 1.956-1T(b)(4)(i)(B) requires linkage between "funding" and a prohibited principal purpose but does not require any linkage between "funding" and the acquisition of U.S. property.

${ }^{46}$ Reg. section 1.956-1T(b)(4)(i)(B) (emphasis added). There may be more than one principal purpose. See T.D. 9733, at 494, 495. The condition also does not require that the funding of FP be by CFC 1 .

${ }^{47}$ The use of a related-person standard here is by analogy to an exception in the definition of U.S. property for stock or debt obligations of an unrelated U.S. corporation. See section 956(c)(2)(F).

${ }^{48}$ Notice 2014-52, 2014-42 IRB 712, 717-718, section 3.01(b).
}

to U.S. taxing jurisdiction. (The interest income of the CFC generally will be subpart F income. It is the borrower's income that is avoiding U.S. tax.) This goes beyond allowing deferral to continue when the return on the investment will be subject to U.S. tax, as would be the case of a loan to another CFC. This clarification of the scope of section 956 avoidance is critical to prevent foreign parent ownership of a U.S. group from having a fundamental advantage over a U.S. parent group. A loan to FP (or any non-CFC affiliate) is not the same as a loan to another $\mathrm{CFC}$, which generally would not result in a section 956 inclusion (absent other reasons to trigger the indirect U.S. property ownership rule), precisely because the return earned by FP with the loan proceeds is outside of U.S. taxing jurisdiction. The rationale underlying Notice 2014-52's treatment of a loan to a non-CFC foreign affiliate is coherent in protecting the U.S. tax base, but it is not and should not be limited to inversions and should not depend on the use to which the CFC earnings are put by the borrower. The regulations should apply in Example 1 without regard to how FP uses the funds from CFC 1.

Example 2: Assume the same facts as in Example 1, except that FP has a wholly owned foreign subsidiary organized in Country C (FSub 2) that conducts business in Country $\mathrm{C}$ and owns no U.S. property. CFC 1 makes a loan to FSub 2 (instead of to FP). Assume that FSub 2 makes a distribution to FP in the same year as or after the year of the loan. Country A employs a dividend exemption system of taxation and FP pays no tax on the dividend. In this example, it is not assumed that FP redeems FP stock after the acquisition of USP; the use of funds by FP is unspecified. The diagram below illustrates this transaction:

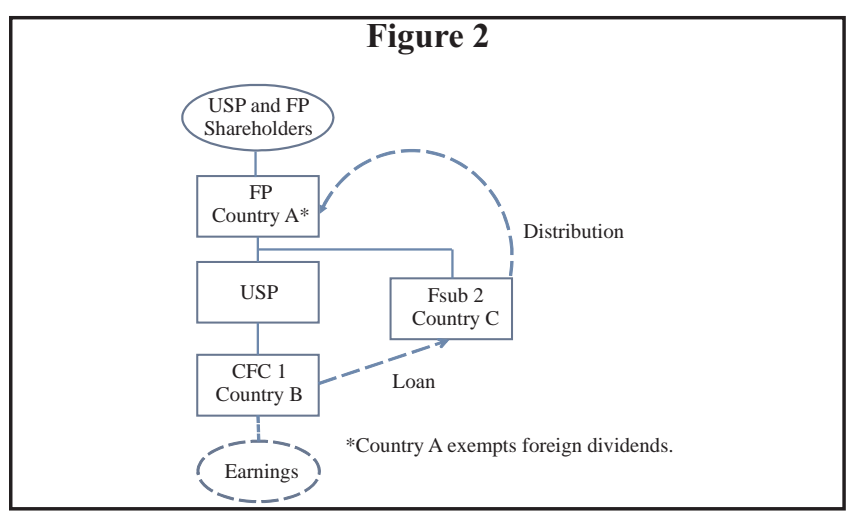

The issue in Example 2 is whether the requisite "funding" of FP may be found. The language of the regulation is quite broad - a dividend from FSub2 can be a "funding." If the "funding by any means" of FP is to avoid the application of section 956 with respect to $C F C 1$, the temporary regulation would 
apply. This reading would be consistent, again, with the rationale underlying the rule in section 3.01(b) of Notice 2014-52.

Under the temporary regulation, the breadth of the rationale for finding a principal purpose is constrained by the requirement that the "funded" foreign corporation also own U.S. property. That constraint would, at first blush, lead to simple work-arounds that, if left unaddressed, would materially undercut the principal purpose rationale just described. A case testing the limits of a broad principal purpose rationale is in the following example.

Example 3: Assume the same facts as in Example 2. CFC 1 again makes a loan to FSub 2, but FSub 2 does not make a distribution or otherwise make funds directly or indirectly available to FP before or after receiving the proceeds of the loan from CFC 1. FSub 2 uses the loan proceeds in its Country B business.

Example 3 is intended to present a case in which a loan is made by CFC 1 to FSub 2 and the proceeds are used in FSub 2's business without any link to FP and the U.S. property held by FP. (This may or may not be a real case since most large companies will have borrowing facilities at the FP level and will secure the borrowing with the assets of the group.) The question is whether the "funding" of FP with shares of USP stock by former USP shareholders is considered to have a principal purpose of avoiding section 956 if CFC 1 makes a loan to an FP subsidiary that is not a CFC. To be consistent with the rationale of the rule in Notice 2014-52, the answer should be that the regulation's principal purpose test is satisfied. The same avoidance occurs in Example 3 as that which is targeted in the loan to a non-CFC foreign member of the expanded affiliated group in section 3.01(b) of Notice 2014-52.

Until its amendment in September 2015, the temporary regulation applied in the discretion of the IRS. In T.D. 9733, however, the regulation was amended to be self-executing. This change more explicitly forces lawyers and accountants as advisers to determine the strength of a position regarding the loan issue, although they presumably would have had to take the regulation into account before this amendment when rendering advice or an opinion.

To summarize, in our view the temporary regulation's antiabuse rule should apply when the untaxed earnings of a CFC are used, directly or indirectly (under section 956 standards as applied in existing regulations), by a foreign parent group that holds U.S. property (including 25 percent or more of the voting stock of a U.S. shareholder of a CFC) to earn a return that is outside U.S. taxing jurisdiction. The existing antiavoidance regulation should apply after any acquisition by a foreign corporation of a U.S. group to treat a loan by a CFC to a non-CFC foreign member of the now expanded affiliated group as an indirect investment in U.S. property. Under current law, the regulation is not limited to cases in which the transaction comes within the scope of the anti-inversion rules of section 7874 .

c. Addressing the decontrol work-around. The application of the temporary regulation to a transaction not covered by Notice 2014-52 may be avoided with yet another work-around, which is to decontrol the CFC before using its earnings outside the reach of U.S. taxing jurisdiction. This workaround, however, applies only to foreign acquirers that avoid the reach of the section 7874 antiinversion rules because Notice 2014-52 limited its CFC anti-decontrol protections to section 7874 expatriation cases. Thus, if a transaction avoids the reach of section 7874 , it could stay outside the reach of the antiavoidance regulation discussed above merely by decontrolling a CFC with untaxed earnings that the group wishes to tap. This highlights that Notice 2015-52 should be revised when implemented in regulations to apply its section 956 rules, including those covering the decontrol of a CFC, ${ }^{49}$ to all foreign ownership cases and not just to section 7874 inversions. ${ }^{50}$

\section{Conclusions}

The signature sounds of the 1998 romantic comedy You've Got Mail were the tones of a land line dialing through a modem, followed by the scratchy electronic Internet connection familiar to AOL users of that era. What is not well appreciated is that when AOL was sold to Verizon in 2015, AOL's legacy dial-up Internet access subscriptions still provided a substantial majority of AOL's income. Similarly, businesses experiencing transformative change must continue to generate cash from legacy businesses as they transition to new business models. The U.S. tax system is in need of serious reform, but in the meantime deficits are climbing again,, 1 and there is a need to collect revenue from the existing system, including from the corporate income tax.

Corporate expatriations are a symptom of a structural weakness in the source taxation rules that

\footnotetext{
${ }^{49}$ See Notice 2014-52, 2014-42 IRB 712, 719-721, section 3.02(e). The rule in the notice should not be limited to preinversion earnings and profits, but should extend to predecontrol earnings and profits.

${ }^{50}$ The modification to the section 304 regulations in Notice 2014-52 was not limited to inverted companies. See Notice 2014-52, 2014-42 IRB 712, 722, section 3.03(b).

${ }^{51}$ See Congressional Budget Office, "The Budget and Economic Outlook: 2016 to 2026" (Jan. 2016), at 1-3.
} 
must be addressed. The inversion phenomenon simply highlights that taxation of foreign-owned U.S. businesses should be brought in line with what a domestic competitor would pay. Since there is little prospect of a legislative response in the foreseeable future, Treasury should close as many loopholes as it can by using its existing regulatory authority. The earnings-stripping rules recommended above should be adopted. The Notice 2014-52 rules that protect against avoidance of U.S. tax on unrepatriated untaxed earnings should be expanded to cover all foreign acquisition cases. Finally, Treasury should employ the existing antiabuse regulations to address use of unrepatriated CFC earnings to benefit foreign parent groups.

\section{IN THE WORKS}

A look ahead to planned commentary and analysis.

Litigating a New York tax case, volume 1: The audit process (State Tax Notes)

Timothy Noonan and Ariele Doolittle outline the audit process in New York and identify the issues that frequently arise during audits.

Taxpayer challenges to retroactive state tax legislation (State Tax Notes)

Tom Cornett and Samantha Hesley summarize various state court decisions from the last 20 years in which taxpayers have challenged the retroactive application of tax legislation on due process grounds.

The missing tax benefit of donor-advised funds (Tax Notes)

John R. Brooks discusses the claimed tax benefits of donor-advised funds and concludes that concerns about them from a tax policy perspective may not be justified.

Notice 2015-79: Validity of the third-country rule (Tax Notes)

Ken Brewer considers whether the thirdcountry rule announced in a recent IRS anti-inversion notice could be invalidated under the non-delegation doctrine or the presumption against extraterritorial effect.

Foreign financial institutions: Beware of undeclared U.S. accounts (Tax Notes International)

William M. Sharp Sr., Alan W. Granwell, and Robert F. Katzberg discuss the increasingly serious consequences facing foreign financial institutions that maintain undeclared accounts held by noncompliant U.S. taxpayers, recommending steps that FFIs can take to minimize U.S. civil and criminal liability when engaging with U.S. customers.

The confusing U.S. tax return filing deadlines for foreign students and scholars (Tax Notes International)

Paula Singer looks at inconsistencies regarding U.S. tax return filing deadlines for resident and nonresident aliens. 